\title{
Residents' Attitude towards Educational Tourism in Malaysia
}

\author{
Asnarulkhadi Abu Samah ${ }^{1}$, Maryam Ahmadian ${ }^{1}$, Sarjit S. Gill ${ }^{1} \&$ Roozbeh Babolian Hendijani ${ }^{2}$ \\ ${ }^{1}$ Department of Social and Development Sciences, Faculty of Human Ecology, Universiti Putra Malaysia, \\ Malaysia \\ ${ }^{2}$ Department of Foodservice and Management, Faculty of Food Science \& Technology, Universiti Putra \\ Malaysia, Malaysia \\ Correspondence: Maryam Ahmadian, Department of Social and Development Sciences, Faculty of Human \\ Ecology, Universiti Putra Malaysia, UPM Serdang, Selangor, 43400, Malaysia. E-mail: marydian50@yahoo.com
}

Received: June 2, 2013 Accepted: July 15, 2013 Online Published: September 29, 2013

doi:10.5539/ass.v9n13p14 URL: http://dx.doi.org/10.5539/ass.v9n13p14

\begin{abstract}
Introduction: Educational tourism is known as an imperative sector in the tourism industry to expand its sustainability. Malaysia is increasingly recognized by students from around the world as the preferred choice for continuing education. Methods: This study used the data collected through a cross-sectional survey among residents in the Klang Valley, Malaysia. Interviewed questionnaires were used during the survey from December 2010 to January 2011. Results: The results showed that there is a significant difference in attitudes of local residents towards educational tourism. The finding also revealed that attention should be focused on the attitudes of residents with various job sectors. Conclusion: The difference between the residents' job is a critical issue in analyzing the impact of educational tourism and community development projects in Malaysia.
\end{abstract}

Keywords: community development, educational tourism, residents, attitude

\section{Introduction}

Community development and tourism has been defined in the context of less developed and developed countries. Currently, tourism is the second highest contributor to Malaysia's Gross Domestic Product (GDP) after manufacturing (Hamzah, 2004). Tourism is turning into an important industry to community development in Malaysia; therefore, there is the need to build a sustainable approach to this sector to address the main concern of tourists. Nowadays, educational tourism is one of the prominent segments of tourism around the world as it creates employment opportunity along with educational, socio-cultural, environmental, and economic development.

Malaysia has achieved a world ranking of 11th in terms of total overseas students' population around the world (MOHE, 2011). This is attained through the rising overseas students' population in Malaysia which has increased above 90,000 or around $2 \%$ of total international student population in the world. Ministry of Higher Education (MOHE) has set a target of 200,000 international students in Malaysia by the year 2020. The rise of international students' population in Malaysia is attributed to the higher education liberalization policy which provides $100 \%$ foreign equity by 2015 (MOHE, 2011).

Educational tourism deals with awareness (Bhuiyan et al., 2010) and it denotes to any program in which participants go to a location as a group with the primary purpose of connecting in a learning practice that is directly related to the place (Rodger, 1998). Educational tourism depends on some fundamentals (e.g. origin, age, gender, income level, occupation, educational status, religious \& socioeconomic condition of an area) which affect the implementation of educational tourism (Bhuiyan et al., 2010).

Through educational tourism, the visitors travel to a location taking on learning experience directly associated with tourism (Bhuiyan et al., 2010). One of the main reasons for this study is that the previous literature has shown the tourism development encompasses some significant negative and positive effects at the local level and the lives of people in the host community. Thus, the role of local community and their attitudes towards educational tourism and its sustainability is a major issue, particularly in a country like Malaysia that tries to diversify the tourism industry.

Beside the benefit of attracting the international students, it should also concern about the attitude of local 
residents towards educational tourism. It was assumed that identified positive attitude exists and significant evidence of the attitude of residents with different job sectors to support educational tourism industry would be found. The main aim of this paper is to evaluate the residents' attitude towards development of educational tourism in Malaysia.

\section{Materials and Methods}

In developing the research questionnaire to measure the residents' attitude towards development of educational tourism, a review of literature was employed based on previous studies. A self-administrated questionnaire consisting two sections was distributed randomly among residents in the Klang Valley area. The first section measured the attitude of residents (adults) with five questions using 5-point Likert scale ( $1=$ strongly disagree to $5=$ strongly agree) (Liu \& Var, 1986; Teye et al., 2002; Samah et al., 2012). However, the residents were also assessed for relevant social and environmental factors in the first section. The second section considered the socio-demographic of respondents. Specifically, this study was carried out in five districts in Selangor namely Bangi, Petaling Jaya, Serdang, Gombak and Shah Alam, and Kuala Lumpur (Federal Territory) which are situated in the Klang Valley, and in Nilai in the district of Negeri Sembilan (an educational township situated next to Klang Valley). Most of public and private universities and colleges are also located there such as Universiti Malaya, Universiti Kebangsaan Malaysia, Universiti Putra Malaysia, Universiti Teknologi Malaysia, International Islamic University Malaysia, Lim Kok Wing University, Sun Way College and INTI College.

The data collection was carried out for two months starting from December 2010 to January 2011 by trained enumerators and supervised by researchers. A convenience sampling method was applied for this research. All respondents were local people nearby the learning institutions and were chosen in a non-random sampling manner. Only local people are engaged as respondents in this study because it is believed that they are more aware of the presence of international students living nearby their residential area.

The responses were collected and investigated to discover if differences in perceptions of educational tourism existed among residents with different job sectors and social classes. A total of 700 valid questionnaires were used in subsequent analysis to examine the attitude of residents towards educational tourism. To discover if any differences exist, one-way ANOVA test was conducted, followed by descriptive analysis in order to profile the respondents. All analysis was achieved using SPSS version 20.0 (SPSS, Inc., Chicago, IL) in data processing and analyzing in order to fulfill the objective of this research. This paper only describes the residents' attitude towards educational tourism development in the Klang Valley, Malaysia.

\section{Results}

A result of the descriptive analysis of the sample is shown in Table 1. Of the 700 questionnaire completed by residents in the Klang Valley area, the mean age of the respondents was 33.46 years old, within the age range of 18-67. Males accounted for $60.4 \%$ of the respondents and female versus male accounted for $39.6 \%$ respondents. The largest number of respondents $(51.6 \%)$ reported middle school as their highest level of education. The results also showed approximately $77.3 \%$ of the respondents were Malay followed by Chinese $(12 \%)$ and Indians (9.7\%). Majority of respondents were Muslim (78.7\%) employed in industrial service (39.7\%). The average salary was RM 3474.91 and it varied so widely among residents from high income (RM 24000.00) to low income earners, while some were unemployed with no income mostly housewives and students (RM.00). 
Table 1. Demographic characteristic of the respondents $(n=700)$

\begin{tabular}{|c|c|c|c|c|c|c|c|c|c|}
\hline Gender & & Education & & Race & & Religion & & Occupation & \\
\hline Male & $\begin{array}{l}423(60 . \\
4 \%)\end{array}$ & $\begin{array}{l}\text { Elementar } \\
\text { y school }\end{array}$ & $\begin{array}{l}35(5 \% \\
)\end{array}$ & Malay & $\begin{array}{l}541(77 . \\
3 \%)\end{array}$ & Muslim & $\begin{array}{l}551(78 . \\
7 \%)\end{array}$ & $\begin{array}{l}\text { Administrat } \\
\text { ion }\end{array}$ & $27(3.9 \%)$ \\
\hline \multirow[t]{6}{*}{ Female } & $\begin{array}{l}277(39 . \\
6 \%)\end{array}$ & $\begin{array}{l}\text { Middle } \\
\text { school }\end{array}$ & $\begin{array}{l}361(51 \\
.6 \%)\end{array}$ & $\begin{array}{l}\text { Chine } \\
\text { se }\end{array}$ & $\begin{array}{l}84(12 \% \\
)\end{array}$ & Buddha & $63(9 \%)$ & Clerical & $37(5.3 \%)$ \\
\hline & & College & $\begin{array}{l}132(18 \\
.9 \%)\end{array}$ & Indian & $\begin{array}{l}68(9.7 \\
\%)\end{array}$ & Christian & $\begin{array}{l}31(4.4 \% \\
)\end{array}$ & Marketing & $\begin{array}{l}244(34.9 \\
\%)\end{array}$ \\
\hline & & $\begin{array}{l}\text { Bachelor } \\
\text { degree }\end{array}$ & $\begin{array}{l}126(18 \\
\%)\end{array}$ & others & $7(1 \%)$ & Hindu & $\begin{array}{l}53(7.6 \% \\
)\end{array}$ & $\begin{array}{l}\text { Not } \\
\text { working }\end{array}$ & $26(3.7 \%)$ \\
\hline & & $\begin{array}{l}\text { Graduate } \\
\text { degree }\end{array}$ & $\begin{array}{l}46(6.6 \\
\%)\end{array}$ & & & 0thers & $2(.3 \%)$ & Operators & $11(1.6 \%)$ \\
\hline & & & & & & & & $\begin{array}{l}\text { Professiona } \\
\text { ls }\end{array}$ & $77(11 \%)$ \\
\hline & & & & & & & & $\begin{array}{l}\text { Services } \\
\text { Industries }\end{array}$ & $\begin{array}{l}278(39.7 \\
\%)\end{array}$ \\
\hline
\end{tabular}

The results of the one way ANOVA test indicated that there were statistically significant differences $(\rho=0.05)$ between respondents with different job categories in at least one of the five statements: (1) the open policy by the government encourages international students to study in Malaysia and promotes educational tourism (see Table 2). Then, Post Hoc tests using the Tukey HSD test showed that the mean score for the residents in general administrative and management jobs was significantly different than other residents in different career sectors. Taken together, these consequences suggest that the local community in occupations such as administration and management sectors have more positive attitude to international students.

\section{Discussion}

The findings of current study with regard to the attitude of residents towards open government policy in tourism industry support many of the results by previous researchers (Zhang et al., 2000; Hamzah, 2004; Liu, 2006). The results of one way ANOVA test (Table 2) indicate that 'the open policy by the government' is the only variable that has significant relationship $(\rho=.043)$ with educational tourism.

However, a ranking of the mean answers for each attitude dimension illustrated in Table 2 uncovers that the local communities in the Klang Valley, Malaysia had the highest level of consistency with the variable named 'government initiative on Malaysia as an educational hub'. The variable with the highest mean score $(\mathrm{M}=3.75)$ also shows the lowest standard deviation of 0.903 which proves an equality of local community attitudes towards this matter.

Table 2. Test of significance between residents with respect to their attitudes on educational tourism (one-way analysis of variance)

\begin{tabular}{llccc}
\hline Variable & $\begin{array}{l}\text { Mean } \\
(\mathrm{n}=700)\end{array}$ & F ratio & P & S.D. \\
\hline $\begin{array}{l}\text { The open policy by the government will encourage } \\
\text { international students to study in Malaysia and promotes } \\
\text { educational tourism. }\end{array}$ & 3.64 & 2.184 & .043 & .957 \\
$\begin{array}{l}\text { The initiative by the government to make Malaysia as an } \\
\text { educational hub will encourage educational tourism. }\end{array}$ & 3.75 & 2.106 & .051 & .903 \\
$\begin{array}{l}\text { I am looking forward to meet international students to learn } \\
\text { about their culture. }\end{array}$ & 3.35 & 1.403 & .211 & .972 \\
$\begin{array}{l}\text { Educational tourism will bring more positive outcomes than } \\
\text { negative outcomes to the Malaysian people. }\end{array}$ & 3.30 & 1.757 & .105 & 1.025 \\
$\begin{array}{l}\text { If I have friends abroad, I would like to encourage them to } \\
\text { send their children to study in Malaysia. }\end{array}$ & 3.72 & .437 & .854 & .952 \\
\hline
\end{tabular}


To facilitate a clearer analysis of educational tourism in Malaysia, several demographic factors of the respondents were analyzed. The results of this study with emphasis on a discrepancy between respondents' occupation prove that different attitudes in host communities should be understood for educational tourism development to achieve the best probability of success. However, the results of the study might not be applicable elsewhere. As previously mentioned, this study was conducted in the place where many public and private universities and colleges located there.

In considering the diverse job sectors, this comparative study has exposed that residents employed in administration and management sectors appear to have higher attitude to international students in Malaysia. This study suggests that government policy makers and tourism stakeholders should focus on providing more jobs to boost educational tourism sector in Malaysia. Nevertheless, the importance of policy implementation by government at national, regional, and local levels requires long term planning. Policy makers and tourism stakeholders should also be responsible for educating and training residents in collaboration with tourism planners to build a new capacity which can be used to support educational tourism in Malaysia.

In addition to setting achievable goals, the residents should be willing partners in this activity. Their readiness to serve as sociable hosts is essential to the success of educational tourism. Previous literatures also cited that residents can be involved in the planning process linked to tourism growth and they should be informed and consulted (Cooke, 1982; Loukissas, 1983). Therefore, there is a need for greater communication between the residents or local communities and government policy makers and tourism stakeholders.

Above all, policy makers may not be aware of negative and perceived effects of educational tourism at the local level. The residents and host communities also may not be of aware policy makers' goals for sustainable tourism development. Consequently, a balance can be attained between tourism stakeholders and local communities through their communication to help a better tourism outcome. This communication may be facilitated by a series of meeting at the local or regional level to discuss local communities' attitude and experience with international students.

The general outcome of the present study is limited because of partial setting of communities involved in the study as well as lack of researches on educational tourism as a sub-sector of tourism market. This article illustrates that different attitudes in host communities are important to educational tourism development. Policy makers in Malaysia should appreciate the fact that increasing the number of international students along with positive community attitudes is crucial to educational tourism development and community capacity building. Nevertheless, further research is needed to verify whether this data will be supported in different states in Malaysia or not.

\section{Conclusion}

Short-term passage to Malaysia for studying is one of the potential ways for educational tourism development. This paper emphasizes on the relationship between residents' attitude and educational tourism in the Klang Valley, Malaysia.

The results of this paper showed that there are differences in the attitude towards educational tourism development among respondents studied. However, there is a need to ensure that all local communities in various professions are included in the debate about educational tourism development. Respondents differed from each other on all five statements addressing attitude but they all accepted that the most important factor is the open government policy for the development of educational tourism industry.

The study also identified differences between the respondents with different careers towards international students. Based on findings from this study, administrators and managers had significantly a more positive attitude towards international students in Malaysia. Thus, the difference between residents' profession is an important factor in analyzing the impact of educational tourism in Malaysia and it will help government's policy make to emerge a better marketing strategy development to be beneficial to both international students and also residents.

Future research should be done to compare the attitudes of different stakeholder groups (e.g. tourists, residents, entrepreneurs \& local government officials) towards educational tourism sector. It is evident that the benefits of educational tourism consist of both tangible (e.g. job creation) and intangible (e.g. cultural impacts) effects which impact on community development plans in Malaysia.

\section{Acknowledgment}

We would like to thank Universiti Putra Malaysia (UPM) for giving us the grant (Research University Grant Scheme - Project No.: 0604101015RU) to conduct the research. 


\section{References}

Bhuiyan, M. A. H., Islam, R., Siwar, C., \& Ismail, S. M. (2010). Educational tourism and forest conservation: Diversification for child education. Procedia-Social and Behavioral Sciences, 7, 19-23. http://dx.doi.org/10.1016/j.sbspro.2010.10.003

Cooke, K. (1982). The concept of a tourist area cycle of evolution: implications for management ofresources. Canadian Geographer, 24, 5-12.

Hamzah, A. (2004). Policy and planning of the tourism industry in Malaysia. The 6th ADRF general meeting, Bangkok, Thailand.

Liu, A. (2006). Tourism in rural areas: Kedah, Malaysia. Tourism Management, 27, 878-889. http://dx.doi.org/10.1016/j.tourman.2005.05.007

Liu, J. C., \& Var, T. (1986). Residents attitudes toward tourism impacts In Hawaii. Annals of Tourism Research, 13, 193-214. http://dx.doi.org/10.1016/0160-7383(86)90037-X

Loukissas, P. (1983). Public participation in community tourism planning: A gaming simulation approach. Journal of Travel Research, 22, 18-23. http://dx.doi.org/10.1177/004728758302200105

MoHE. (2011). Higher education indicators 2009-2010. Putrajaya: Research and Planning Division.

Peter, J. P., \& Olson, J. C. (2010). Consumer behavior \& marketing strategy (9th ed.), 28-31. New York: McGraw-Hill.

Samah, A. A., Ahmadian, M., Gill, S. S., \& Hendijani, R. B. (2012). Factors Affecting Educational Tourism Development among Local Communities in the Klang Valley, Malaysia. Life Science Journal, 9(4), 3298-3303.

Teye, V., Sirakaya, E., \& S“onmez, S. F. (2002). Residents' attitudes toward tourism development. Annals of Tourism Research, 29(3), 668-688. http://dx.doi.org/10.1016/S0160-7383(01)00074-3

Zhang, G., Pine, R., \& Zhang, H. Q. (2000). China’s international tourism development: present and future. International Journal of Cotemporary Hospitality Management, $12(5), \quad 282-290$. http://dx.doi.org/10.1108/09596110010339634

\section{Copyrights}

Copyright for this article is retained by the author(s), with first publication rights granted to the journal.

This is an open-access article distributed under the terms and conditions of the Creative Commons Attribution license (http://creativecommons.org/licenses/by/3.0/). 